UDC 159.923-159.98

DOI: $10.52534 / \mathrm{msu}-\mathrm{pp} .7(3) .2021 .126-133$

Olena A. Miroshnychenko*

Ivan Franko Zhytomyr State University

10008, 40 Velyka Berdychivska Str., Zhytomyr, Ukraine

\title{
Psychological Background of Age Differences in the Adaptation of Ukrainian Winterers to Living Conditions in Antarctica
}

\section{Article's History: \\ Received: 10.04.2021 \\ Revised: 23.06.2021 \\ Accepted: 07.07.2021}

\section{Suggested Citation:}

Miroshnychenko, O.A. (2021). Psychological background of age differences in the adaptation of Ukrainian winterers to living conditions in Antarctica. Scientific Bulletin of Mukachevo State University. Series "Pedagogy and Psychology", 7(3), 126-133.

\begin{abstract}
The relevance of the article stems from the fact that every year for 26 years, the expedition of winterers goes to the Ukrainian Antarctic Station "Vernadsky Research Base" to carry out scientific research. Their effective adaptation to extreme conditions of life provides qualitative psychological diagnostics and psychological recommendations. The purpose of this article is to provide a theoretical justification and empirical evidence of the specific features of Ukrainian winterers' age in the process of adaptation to the Antarctica conditions. To achieve the results of the study, the article uses the method of sociometric measurement J. Moreno, method of distributing topics by rank, questionnaire. The authors of the article analysed scientific works on the research problem, clarified the concept of "adaptation" and "adaptability" and age limits of the groups of winterers, described methodological tools and conducted empirical research on the specific features of the age of winterers groups during the adaptation. The article justifies the distribution and identifies groups of high, medium and low adaptability to life under extreme conditions in Antarctica. The authors analysed both the data from the empirical study and the interviews with the surveyed winterers. The study's conclusions are: senior winterers have more experience adapting to extreme conditions than younger generations. They can build better interpersonal relationships in a closed community and easily carry distance from home and homesickness. The study revealed that senior persons (especially representatives of the "Generation of winners' children") motivate wintering in Antarctica with a desire for self-fulfilment, being worthy representatives of Ukraine on a distant continent, and feeling responsible for discharging their duties. After all, they are governed by more professional and social motivations that help to better adapt to extreme conditions. The practical value of the work is to develop tools for psychological diagnosis and to provide guidance on the selection of winterers among candidates for wintering
\end{abstract}

Keywords: personality, adaptability, age groups, modern generations, extreme living conditions

\section{INTRODUCTION}

The relevance of the chosen subject stems from the fact that Ukraine is one of the 19 countries in the world that have permanently active Antarctic stations on the sixth continent, Antarctica. Members of the Ukrainian Antarctic Expeditions carry out scientific research in such fields as biology, hydrometeorology, geophysics, geology, engineering, psychology and psychophysiology. Until 1991, Ukrainian scientists explored the sixth continent as part of Soviet expeditions. After gaining independence, Ukraine joined the international "Antarctic Treaty", and in 1996 in Antarctica, the Ukrainian flag was raised above the station "Vernadsky Research Base". Such an essential international mission poses significant challenges for Ukrainian scientists. The development of Ukrainian science and international cooperation is more dependent on the psychological training of Ukrainian winterers, who work in the Antarctic conditions. Winterers have to work in extreme conditions due to exposure to low temperatures, time and climate zones changes, sensory deprivation, psychological specific features of work, having rest in a limited team, etc. 
Both Ukrainian and foreign scientists research the problem of adaptation to Antarctic conditions through the lens of various aspects. E. Moiseyenko and G. Pyshnov investigate the physiological features of the adaptation of winterers $[1 ; 2]$. For example, scientists have found that both members of Ukrainian Antarctic expeditions and members of such professions as air traffic controllers, electronics engineers, and fire-fighters experience chronic fatigue depending on the level of work tension. At the same time, the authors have developed approaches for determining and preventing burnout, taking into account different mechanisms for the development of chronic fatigue of specialists. For his part, A. Gordieiev develops information technologies of professional selection of winterers taking into account the psychophysiological state of organism [3]. For professional selection, the author created a computer software system and accumulated a specialised database. The developed technology was experimentally implemented based on the Department of Biocybernetics and Aerospace Medicine of the National Aviation University (Kyiv).

For example, O. Kokun and L. Bakhmutova investigate psychological features of interaction of Ukrainian expeditions members in limited collective conditions $[4 ; 5]$. The authors identified three areas of winterers' interaction during wintering (professional, personal, leisure) and provided psychological recommendations to optimise interpersonal relations in a limited community. At the same time, foreign researchers M. Mehta and G. Chugh are investigating the psychological aspect of motivation to the activities of winterers of Indian Antarctic stations [6]. Researchers have found that an essential role in adapting to extreme conditions has features from the individual's social sphere that help adjust to unusual activity, namely: responsibility for personal actions, vivacity, positive outlook on the future, courage, patience, and kindness comrades. The studies of O.Miroshnychenko and I. Pasichnyk concern age aspects of preparedness and individual typological features of Ukrainian winterers [7-9].

The purpose of this article is to provide a theoretical justification and empirical evidence of the age peculiarities of the adaptation of Ukrainian winterers to extreme conditions in Antarctica. The objectives of the study are: to analyse scientific works on the given problem, clarify the concept of "adaptation" and "adaptability", justify age boundaries of investigated winterers' groups, describe methodological tools and conduct empirical research on the adaptation of winterers' age groups, identify groups of high, medium and low adaptability to life under extreme conditions in Antarctica.

\section{LITERATURE REVIEW}

The concept of "adaptation" and "adaptability" is one of the main concepts in the study, which requires detailed analysis. First of all, adaptation is a process of adapting individuals to changing conditions, in the case of the study, to extreme conditions in Antarctica. The human being has to adapt both physiological mechanisms of the organism (cold, sensory deprivation, meteorological-climatic complications, magnetic effects), psychological processes ("detachment" from the home and relatives, need to communicate with a limited number of expedition members, psycho-emotional overloads during the daily shift, etc.). A. Nalchajyan has a similar view on the concept of adaptation [10]. The researcher believes that the process of adaptation is a complex and multi-layered phenomenon of the adaptation of an individual in both micro-environment and macro-environment. The author argues that a well-adapted person has a balance between productivity, the ability to enjoy life and mental processes [10].

Reflecting on the concept of adaptability, we believe that it is a natural (at the physiological level) and acquired (at the psychological level) capacity of a person to adapt, that is, to adapt various manifestations of life to changed conditions. J. Piaget made a fundamental contribution to the development of adaptability [11]. He considers the process of adaptation in both biology and psychology as a unity of oppositely directed processes of accommodation and assimilation. The author considers accommodation as an adaptation to an environment that ensures the organism's functioning under environmental conditions. In contrast, assimilation is the process of changing the very components of the environment, processing them according to the organism's needs. These processes are closely interlinked and mutually reinforcing, but only one of them plays a leading role in a particular case.

The researcher N. Danilenko, following V. Garbuzov, attributes to the possibilities of human adaptation such elements as instincts, temperament, constitutional peculiarities, emotional-voluntary sphere, properties of intellect, abilities, physical condition and even features of appearance. A high level of adaptability means good psychophysical qualities, high working ability, stamina, stress tolerance, mental and physical harmony, the harmony of innate and developed personal attributes. The authors believe that the level of a person's adaptability may increase or decrease due to the influence of upbringing, education, environment and lifestyle [12]. After all, we believe that adaptation, in particular in extreme conditions, can be more effective if a specialist has a positive motivation to act. A person's level of adaptability can also increase due to personal orientation, a system of values, goals and needs, etc.

It should be noted that A. Maklakov identifies the concept of personal adaptive capacity as an essential component of adaptive capacity - the development level of psychological characteristics determines the range of environmental factors to which a person has to adapt [13]. For his part, E. Larssen argues that the realisation of a dream comes when a person can work in extreme conditions, even when pushing beyond proper limits. The author developed a methodology to become stronger and more resilient for living in extreme conditions, and gave such training the name "Hell Week". It helps in training paratroopers and athletes in extreme sports in Norway. The conclusion of this method is as follows: to achieve success (and, therefore, to 
adapt to extreme living conditions), a person must be highly motivated and train a lot. It is also quite relevant to the winterers during Ukrainian Antarctic expeditions.

\section{MATERIALS AND METHODS}

To determine the psychological background of age differences in the adaptation of Ukrainian winterers to living conditions in Antarctica, the authors relied on the technical and psychological tasks programme of the National Antarctic Scientific Centre of Ukraine (NANC), approved by the Scientific and Technical Council of the Centre in the spring of each year, before the start of the next Ukrainian Antarctic expedition. The author conducted empirical research between 2011 and 2020. Members of Ukrainian Antarctic Expeditions took part in the research and performed professional duties at the "Vernadsky Research Base" station for 12-13 months. The total number of people surveyed was 71 (69 male, 2 female); respondents were between 23 and 63 .

The scientific work consisted of several stages. The first stage is data collection. In order to determine the age characteristics of adaptation to extreme conditions in Antarctica, the subjects were divided according to three criteria: 1) number of winterings; 2) social status of the expedition member; 3 ) presence of personal traits. The logic of the reasoning was as follows. The number of winterings indicates whether a person has adapted to extreme conditions, whether it seems acceptable, and whether an expedition member wants to return to it. The largest number of wintering among the subjects was 8 , the smallest -1 . In this way, based on the amount of land, the authors built a rating of winterers.

As for social status, the higher it is, the better the expedition member has adapted to the team and specific features of relations in socio-psychological and naturally extreme conditions. To determine the sociometric status of expedition members, the authors used J. Moreno's method of sociometric measurement with modifications: sociometric preferences were measured in three spheres - work, personal relationships, leisure activities. The subjects were to answer 3 questions: "Which of the expedition members would you rather work with on the station?", "Which member of the expedition will you tell of your problems?" and "Who do you like to spend your free time with when you are off duty?". It was necessary to select 3 people for each question. The psychologist conducted the study while maintaining the confidentiality of the results. After processing the questionnaires, the authors compiled the rating of winterers separately in each expedition. The first person in the rating had the highest number of points - 12 (by the number of winterers in the expedition), the last person in the group - the lowest - 1 point.

The third indicator is certain personality traits defined by the entrusted expert group, including the Head and Senior Scientific Associate of the Medical and Psychological department of National Antarctic Scientific Centre of Ukraine and the Heads of Ukrainian expeditions during ten studied years. Thus, during the years of the study, the Head and the Senior Scientific Associate carried out psychological examinations of the winterers during their selection, preparation for wintering, and psychological support from the mainland via telephone and internet connection with the station. For their part, expedition heads directly supervised, took care of subordinates, and were responsible for them to the NANC, MES and their close relatives. As a result, they can objectively and impartially characterise the adaptation of winterers to Antarctic conditions. In total, the expert group included 17 people. A preliminary survey was conducted with a team of winterers from the three previous expeditions (36 persons in total) to objectively present the personality characteristics required for living in the Antarctic environment who wintered in different years during the study period. They answered the question: "What are the 10 personality traits that are most important, in your opinion, for a winterer who works during a year at the Ukrainian Antarctic Station?". The authors created a questionnaire for the expert group, representing the first ten essential personality traits mentioned by the winterers and their names in alphabetical order. The experts were given the following instructions:

\section{"DEAR MEMBER OF THE EXPERT GROUP,}

We ask you to participate in the scientific research of the "Personality type of Ukrainian winterer in Antarctica". To do this, please answer the questions of our questionnaire: What qualities do you think every Ukrainian winterer has in the proposed list?" (these ten basic qualities were given by Ukrainian winterers and presented in alphabetical order). Mark clearly expressed qualities with the number 3, moderately expressed - 2, weakly expressed - 1, not expressed - 0. The questionnaire is anonymous".

Table 1 gives an example of how expert group participants completed the questionnaire.

Table 1. Example of filling in the questionnaire by expert group participants

\begin{tabular}{|c|c|c|c|c|c|c|c|c|c|c|c|}
\hline$\stackrel{\dot{\theta}}{Z}$ & 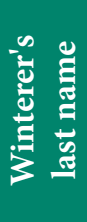 & 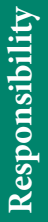 & 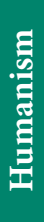 & 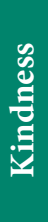 & 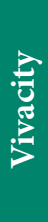 & $\begin{array}{l}\frac{1}{5} \\
\frac{0}{2} \\
\frac{0}{0} \\
\frac{8}{0}\end{array}$ & $\underset{8}{\stackrel{B}{8}}$ & 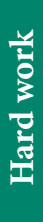 & 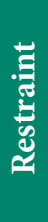 & $\begin{array}{l}\frac{8}{8} \\
\frac{3}{0} \\
\frac{0}{0} \\
\end{array}$ & 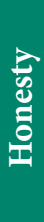 \\
\hline 1 & A & 3 & 3 & 2 & 3 & 3 & 1 & 2 & 3 & 1 & 2 \\
\hline 2 & B & 2 & 2 & 3 & 3 & 3 & 2 & 1 & 1 & 2 & 2 \\
\hline
\end{tabular}


Table 1, Continued

\begin{tabular}{|c|c|c|c|c|c|c|c|c|c|c|c|}
\hline$\dot{\mathbf{Z}}$ & 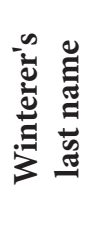 & 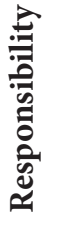 & 祸 & $\underset{\mathscr{E}}{\mathscr{E}}$ & 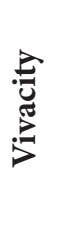 & ن & 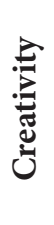 & 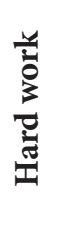 & 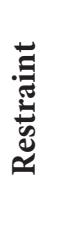 & 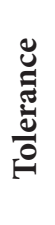 & 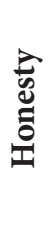 \\
\hline 3 & $\mathrm{C}$ & 3 & 2 & 2 & 3 & 3 & 2 & 3 & 1 & 1 & 3 \\
\hline 4 & $\mathrm{D}$ & 3 & 3 & 2 & 2 & 1 & 2 & 3 & 3 & 1 & 2 \\
\hline 5 & $\mathrm{E}$ & 3 & 3 & 3 & 3 & 2 & 3 & 2 & 2 & 2 & 3 \\
\hline 6 & $\mathrm{~F}$ & 2 & 3 & 1 & 2 & 2 & 2 & 3 & 3 & 1 & 3 \\
\hline 7 & $\mathrm{G}$ & 3 & 0 & 2 & 1 & 3 & 0 & 1 & 1 & 1 & 1 \\
\hline 8 & $\mathrm{H}$ & 3 & 2 & 2 & 3 & 3 & 3 & 3 & 2 & 2 & 1 \\
\hline 9 & I & 2 & 2 & 2 & 1 & 3 & 3 & 3 & 3 & 2 & 1 \\
\hline 10 & $\mathrm{~J}$ & 3 & 2 & 3 & 3 & 2 & 2 & 3 & 3 & 3 & 3 \\
\hline
\end{tabular}

The next stage of the study was the processing of the received data. The results of all three studies (wintering rating, sociometric rating, and personality rating) led to a single measurement. As 12 was the highest number in the sociometric ranking, other studies were also included, in particular: since the largest number of winterings was 8 , it was multiplied by coefficient of 1.5 ; personality indicators were added and divided by coefficient of 2.5 . Thus, all the selected criteria were measured in the same calculation system.

Quantitative analysis was also used from the group of data processing methods: mathematical statistics; comparison of average values by parametric and non-parametric methods. In distributing subjects by adaptive level, the authors used the method of distributing the features of psychological phenomena by rank [15]. At the same time, the authors used qualitative analysis of the obtained data: differentiation of the material by subject types. From the group of interpretive methods, the study included structural and qualitative interpretation of the results.

\section{RESULTS AND DISCUSSION}

First of all, the study aims at defining the age specific features of the winterers' adaptability. The authors based their age categories on the opinion of K. Krutii and L. Zdanevic, known for providing a social and psychological basis for identifying age periods in modern adult life [16]. The proposed periodisation derives from the theory of generations, according to which modern adults are divided into age groups depending on the year of birth: 1947-1967 CE generation "Children of the winners", born after the Second
World War (in the study - winterers of the senior age group 46-63); 1968-1987 CE - generation "X" (in the study winterers of the average age group 35-45); 1988-2000 CE generation "Y" (in the study - winterers of the junior age group 22-34).

All age categories of the study had to answer the questionnaire concerning the basic personality traits of the winterers. According to the author, an interesting result is that it demonstrated which qualities are the most significant for people who work in extreme conditions for more than a year in a row. During the survey, the winterers had to answer which personal traits were most important for the life in Antarctica. The following data were obtained. In general, winterers named 42 qualities, combined into synonymous "nests" and built into the rating system basing on their repetitions. The authors have thus identified 25 qualities necessary for life in Antarctica in the view of the winterers. Consequently, they are presented in descending order of necessity: honesty; collectivism, sociability; creativity, ingenuity; responsibility; kindness; restraint, balance; hard work; humanity, humanism; toleration, tolerance; vivacity, sense of humour; sincerity, openness; intelligence, erudition; willpower, perseverance; activity, energy; sportiness, physical force and stamina; decency, justness; loyalty, reliability; professionalism; courage; sociability; artistry, musicality; patriotism; discipline; daydream; modesty.

After completing and processing all the questionnaires (converting to a single measurement system with coefficients), the series of indicators of each winterer have been compiled into one table (Table 2).

Table 2. Distribution of winterers by number of winterings, sociological status and assessment of winterers' traits by expert team

\begin{tabular}{|c|c|c|c|c|c|c|c|}
\hline No. & Initials & Age group & $\begin{array}{l}\text { Points for } \\
\text { winterings }\end{array}$ & $\begin{array}{l}\text { Sociometric } \\
\text { score }\end{array}$ & $\begin{array}{c}\text { General } \\
\text { score }\end{array}$ & $\begin{array}{l}\text { Final } \\
\text { score }\end{array}$ & $\begin{array}{l}\text { Average score } \\
\text { for } 3 \text { indicators }\end{array}$ \\
\hline 1 & S. M. & Senior & 12 & 11 & 9.8 & 32.8 & 10.9 \\
\hline 2 & G. B. & Average & 12 & 10 & 9.6 & 31.6 & 10.4 \\
\hline
\end{tabular}


Table 2, Continued

\begin{tabular}{|c|c|c|c|c|c|c|c|}
\hline No. & Initials & Age group & $\begin{array}{l}\text { Points for } \\
\text { winterings }\end{array}$ & $\begin{array}{c}\text { Sociometric } \\
\text { score }\end{array}$ & $\begin{array}{c}\text { General } \\
\text { score }\end{array}$ & $\begin{array}{l}\text { Final } \\
\text { score }\end{array}$ & $\begin{array}{l}\text { Average score } \\
\text { for } 3 \text { indicators }\end{array}$ \\
\hline 3 & O. V. & Junior & 7.5 & 8.5 & 11.9 & 27.9 & 9.3 \\
\hline 4 & M. P. & Average & 4.5 & 12 & 11. & 27.8 & 9.3 \\
\hline 5 & R. A. & Senior & 4.5 & 11.5 & 11.5 & 27.5 & 9.2 \\
\hline 6 & D. I. & Average & 4.5 & 11 & 11. & 26.8 & 8.9 \\
\hline 7 & D. K. & Average & 6 & 9.5 & 10.2 & 25.7 & 8.6 \\
\hline 8 & O. Yu. & Junior & 9 & 7.4 & 9.3 & 25.7 & 8.6 \\
\hline 9 & Z.O. & Junior & 7.5 & 8 & 9.9 & 25.4 & 8.5 \\
\hline 10 & L. D. & Average & 6 & 7.75 & 11.6 & 25.4 & 8.5 \\
\hline 11 & B. O. & Average & 10.5 & 6.1 & 8.0 & 24.6 & 8.2 \\
\hline 12 & N.S. & Senior & 6 & 8 & 10.5 & 24.5 & 8.2 \\
\hline 13 & V. M. & Average & 4.5 & 8.5 & 11.48 & 24.5 & 8.2 \\
\hline 14 & S. V. & Senior & 6 & 8 & 10.5 & 24.5 & 8.2 \\
\hline 15 & A. O. & Junior & 3 & 10.25 & 11.0 & 24.2 & 8.2 \\
\hline 16 & S. P. & Average & 7.5 & 4.8 & 10.8 & 23.1 & 7.8 \\
\hline 17 & L. V. & Senior & 9 & 6.7 & 6.8 & 22.5 & 7.3 \\
\hline 18 & V. P. & Average & 1.5 & 9 & 11.32 & 21.8 & 7.3 \\
\hline 19 & D. A. & Junior & 3 & 7.6 & 11.2 & 21.8 & 7.2 \\
\hline 20 & G. O. & Average & 1.5 & 9.5 & 10.6 & 21.6 & 7.2 \\
\hline 21 & M. O. & Junior & 1.5 & 9 & 11.0 & 21.5 & 7.2 \\
\hline 22 & P. O. & Junior & 6 & 5.4 & 10.1 & 21.5 & 7.2 \\
\hline 23 & G. A. & Junior & 3 & 8.5 & 10.0 & 21.5 & 7.2 \\
\hline 24 & H. V. & Senior & 3 & 8 & 10.4 & 21.4 & 7.1 \\
\hline 25 & S. O. & Junior & 3 & 7.1 & 11.2 & 21.3 & 7.1 \\
\hline 26 & F. Yu. & Senior & 1.5 & 10 & 9.6 & 21.1 & 7.0 \\
\hline 27 & N. I. & Senior & 6 & 4 & 10.84 & 20.8 & 6.8 \\
\hline 28 & K. E. & Average & 4.5 & 5 & 10.92 & 20.4 & 6.8 \\
\hline 29 & S. V. & Average & 3 & 7 & 10.4 & 20.4 & 6.7 \\
\hline 30 & O. A. & Junior & 3 & 5.75 & 11.2 & 20.0 & 6.6 \\
\hline 31 & P. B. & Junior & 3 & 6 & 10.6 & 19.6 & 6.5 \\
\hline 32 & N. O. & Average & 3 & 6 & 10.4 & 19.4 & 6.5 \\
\hline 33 & B. M. & Average & 1.5 & 6.5 & 11.2 & 19.2 & 6.4 \\
\hline 34 & L. Yu. & Average & 4.5 & 5.8 & 8.4 & 18.7 & 6.2 \\
\hline 35 & B. B. & Junior & 1.5 & 6.5 & 10.4 & 18.4 & 6.1 \\
\hline 36 & D. I. & Average & 1.5 & 8 & 8.4 & 17.9 & 6.0 \\
\hline 37 & S. O. & Senior & 1.5 & 4.5 & 11.32 & 17.3 & 5.8 \\
\hline 38 & A. I. & Average & 1.5 & 5 & 10.8 & 17.3 & 5.8 \\
\hline 39 & M. V. & Average & 1.5 & 6 & 9.2 & 16.7 & 5.6 \\
\hline 40 & K. P. & Junior & 1.5 & 3.5 & 6.6 & 16.6 & 5.5 \\
\hline 41 & P. D. & Average & 3 & 3 & 10.52 & 16.5 & 5.5 \\
\hline 42 & M. V. & Junior & 1.5 & 3 & 11.6 & 16.1 & 5.5 \\
\hline 43 & G. P. & Average & 1.5 & 5 & 9.6 & 16.1 & 5.5 \\
\hline 44 & G. Yu. & Average & 3 & 4 & 9.0 & 16.0 & 5.4 \\
\hline
\end{tabular}


Table 2, Continued

\begin{tabular}{|c|c|c|c|c|c|c|c|}
\hline No. & Initials & Age group & $\begin{array}{l}\text { Points for } \\
\text { winterings }\end{array}$ & $\begin{array}{c}\text { Sociometric } \\
\text { score }\end{array}$ & $\begin{array}{l}\text { General } \\
\text { score }\end{array}$ & $\begin{array}{l}\text { Final } \\
\text { score }\end{array}$ & $\begin{array}{l}\text { Average score } \\
\text { for } 3 \text { indicators }\end{array}$ \\
\hline 45 & S. V. & Senior & 4.5 & 1 & 10.28 & 15.8 & 5.3 \\
\hline 46 & H. P. & Senior & 3 & 2.25 & 10.3 & 15.6 & 5.2 \\
\hline 47 & M. M. & Senior & 1.5 & 5.5 & 8.4 & 15.4 & 5.1 \\
\hline 48 & B. N. & Average & 1.5 & 4 & 9.8 & 15.3 & 5.1 \\
\hline 49 & N. A. & Junior & 1.5 & 3 & 10.8 & 15.3 & 5.1 \\
\hline 50 & L. D. & Average & 1.5 & 3 & 10.52 & 15.0 & 5.0 \\
\hline 51 & S. A. & Average & 1.5 & 3 & 10.0 & 14.5 & 4.8 \\
\hline 52 & S. A. & Junior & 3 & 3.75 & 7.6 & 14.4 & 4.8 \\
\hline 53 & B. T. & Average & 1.5 & 1 & 11.2 & 13.7 & 4.6 \\
\hline 54 & K. O. & Junior & 1.5 & 1 & 10.6 & 13.1 & 4.4 \\
\hline 55 & P. V. & Junior & 1.5 & 2 & 9.4 & 12.9 & 4.3 \\
\hline 56 & B. E. & Junior & 3 & 2.5 & 7.2 & 12.7 & 4.2 \\
\hline 57 & D. O. & Junior & 1.5 & 6.5 & 4.68 & 12.7 & 4.2 \\
\hline 58 & P. D. & Junior & 1.5 & 1 & 10.0 & 12.5 & 4.2 \\
\hline 59 & K. V. & Average & 1.5 & 8 & 2.8 & 12.3 & 4.1 \\
\hline 60 & R. A. & Junior & 3 & 1.25 & 7.72 & 12.0 & 4.0 \\
\hline 61 & P. E. & Average & 1.5 & 1.5 & 8.8 & 11.8 & 3.9 \\
\hline 62 & Ch. A. & Junior & 1.5 & 3 & 6.6 & 11.1 & 3.7 \\
\hline 63 & K. O. & Junior & 1.5 & 2 & 7.4 & 10.9 & 3.6 \\
\hline 64 & M. O. & Junior & 1.5 & 4 & 5.32 & 10.8 & 3.6 \\
\hline 65 & Z. A. & Junior & 1.5 & 1 & 8.2 & 10.7 & 3.6 \\
\hline 66 & Zh. G. & Junior & 1.5 & 1 & 8.0 & 10.5 & 3.5 \\
\hline 67 & M. O. & Average & 1.5 & 1 & 7.6 & 10.1 & 3.4 \\
\hline 68 & Sh. R. & Junior & 1.5 & 1 & 6.8 & 9.3 & 3.1 \\
\hline 69 & L. O. & Junior & 1.5 & 2 & 5.6 & 9.1 & 3.0 \\
\hline 70 & Zh. V. & Average & 1.5 & 1.5 & 5.2 & 8.2 & 2.7 \\
\hline 71 & O. P. & Average & 1.5 & 1 & 4.52 & 7.0 & 2.3 \\
\hline
\end{tabular}

The average score of the overall rating presented in Table 2 is 6.1 , almost the same as the median. It equals 6.0. To differentiate between groups with high, medium and low adaptability, the principle of dividing the sample by groups with the criterion of standard deviation from the mean value by $1 / 2$ was used. The calculations were carried out using estimates of the distribution of the values of psychological phenomena [14; p. 20-23]. The group with average adaptability includes winterers with an average overall rating of 7.0-5.2 points, which is a deviation of values from the average value (6.1 points) of $1 / 2$ standard deviation (the standard deviation is 1.88 points, respectively, $1 / 2$ standard deviation is 0.94$)$. So, the average group includes 21 wintering grounds, which is $29.6 \%$ of the study sample. The group with high and low levels of adaptability includes 25 people each (35.2\% each). Table 3 clearly shows their distribution by age groups.

Table 3. Distribution of age groups of winterers by adaptive levels

\begin{tabular}{|c|c|c|c|}
\hline \multirow{2}{*}{ Age groups of winterers } & \multicolumn{3}{|c|}{ Adaptability levels } \\
\hline & High & Medium & Low \\
\hline Senior (12 people) & $6(50.0 \%)$ & $5(41.7 \%)$ & $1(8.3 \%)$ \\
\hline Average (30 people) & $10(33.3 \%)$ & $11(36.7 \%)$ & $9(30.0 \%)$ \\
\hline Junior (29 people) & $9(31.0 \%)$ & $5(17.2 \%)$ & $15(51.7 \%)$ \\
\hline
\end{tabular}


As you can see, among the representatives of the senior age group “Generation of winners' children”, 91.7\% are people with a high and medium level of adaptability; among the representatives of the middle age group "Generation X", $70 \%$ of people have a high and medium level of adaptability; among the representatives of the junior age group "Generation Y", there are only $48.2 \%$ winterers of high and medium level of adaptability.

Based on an analysis of empirical evidence, the conclusions on age-specific adaptability of winterers are as follows. In the author's study, the senior generation appeared to be the most adapted group. The study found that they have more experience adjusting to challenging conditions, higher ranking in social relations and a higher degree of personality qualities needed to function in extreme conditions. As for motivation to live in Antarctic conditions, members of the junior age group are often moved by romanticism, admire the beauty of an unusual nature and want to "test themselves". They are also more likely than members of the middle and senior groups to be attracted by the possibility of material reward for working in extreme conditions.

For representatives of middle and senior age (especially representatives of "Generation of winners' children"), the motives of self-fulfilment, desire to be worthy citizens of Ukraine, even away from the Motherland, are the most significant. They also have a sense of responsibility for the performance of their professional duties. Hence, they have professional and social motivations that contribute to better adaptation to extreme conditions.

Similar data can be observed in other authors. Thus, O. Sannikov notes in his works that personality's proactive stance and autonomy in decision-making helps in dealing with negative influences of stress situations [17]. As for members of other segments of the population who occasionally find themselves in stressful situations, they are also trying to adapt to extreme conditions by various means. Thus, G. Pirog examined the means and techniques used by students to relieve stress, especially after the examination session, which is a seriously stressful situation in the author's opinion. Such techniques are: walking in the fresh air (used by about $80 \%$ of respondents); sleeping and communicating with loved ones (75\%); delicious food and physical activity (50\% of students each) [18, p. 195].

Winterers at the Antarctic station resort to similar techniques: they organise various competitions in the open air during periods with favourable temperatures; they have a full sleep; the station's doctor takes care of their health. It is worth adding that there are conditions for winterers to practice sports on the Antarctic station "Vernadsky Research Base": there is a sports hall, a billiard room, and sports games when the weather is favourable. There is also a time and a place for leisure activities - library, coffee bar, break room. Since 2020, there is an Internet connection for better communication with relatives. All this contributes to better adaptation of Ukrainian winterers to life in Antarctic conditions.

\section{CONCLUSIONS}

The article presents an analysis of scientific works of Ukrainian and foreign authors on the adaptation of the person to extreme conditions, provides the interpretation of "adaptation" and "adaptability" concepts. Based on the socio-psychological theory of generations, the work justifies the distribution of participants in Ukrainian Antarctic expeditions by age groups. Thus, the authors have defined 3 age groups of winterers: the senior group ("Children of winners"), the middle age group (generation " $\mathrm{X}$ ") and the lower age group (generation "Y"). In the course of the research, empirical research on adaptation in certain age groups was carried out.

As a result of the study, the authors determined the criteria for dividing winterers into groups for the effectiveness of adaptation to Antarctic conditions: number of winters, sociometric status, personal qualities of winterers. Based on empirical research, the authors have identified groups of high, medium and low adaptability to life under extreme conditions. It was proved that the senior generation appeared to be the most adapted group in the author's study. In conducting conversations with representatives of this group, it turned out that the most significant motivation for them in their desire to spend the winter in Antarctica is professional and social motivation.

\section{REFERENCES}

[1] Moiseyenko, Ye.V., Sukhorukov, V.I., Pyshnov, G.Yu., Mankovska, I.M., Rozova, K.V., Kovalevska, O.E., Madjar, S.A., Bubnov, R.V., Gorbach, A.O., Danylenko, K.M., Moiseyenko, O.I., \& Miroshnichenko, O. (2016). Antarctica challenges the new horizons in predictive, preventive, personalized medicine: Preliminary results and attractive hypothesis for multidisciplinary prospective studies in the Ukrainian "Akademik Vernadsky" station. EPMA Journal, 7(1), article number 11.

[2] Pyshnov, H.Yu. (2011). Approaches to assess the degree of burnout in individuals with tense work with the help of logistic models. Ukrainian Medical Journal, 3, 101-105.

[3] Gordieiev, A.D. (2016). Development of information technology of the process of professional selection of operators of extreme activities. Technology Audit and Production Reserves, 5/1(31), 11-16.

[4] Kokun, O., \& Bakhmutova, L. (2020). Dynamics of indicators of expeditioners' psychological states during long Antarctic stay. International Journal of Psychology and Psychological Therapy, 20(1), 5-12.

[5] Kokun, O., \& Bakhmutova, L. (2021). The impact of expeditioners' personality traits on their interpersonal interactions during long-term Antarctic expeditions. Polish Polar Research, 42(1), 59-76. 
[6] Mehta, M., \& Chugh, G. (2011). Achievement motivation and adjustment in members of Indian scientific expedition to Antarctica. Psychological Studies, 56(4), article number 404.

[7] Miroshnychenko, O.A. (2016). Role winterer's temperament in the process of adaptation to the living conditions in Antarctica. Science and Education, 7, 126-132.

[8] Miroshnychenko, O., Pasichnyk, I., Voznyuk, A., Kubitskyi, S., Roganova, M., Tsvietkova, H., Shorobura, I., \& Bloshchynskyi, I. (2020). Study of Ukrainian Polar Explorers' psychological readiness for extreme environments at the Antarctic station. International Journal of Human Movement and Sports Sciences, 8(6), 455-461.

[9] Miroshnichenko, O.A., \& Pasichnyk, I.D. (2020). The readiness of Ukrainian winterers to life in an Antarctic station. Scientific Journal of National Pedegogical Dragomanov University. Series 12. Psychological Sciences, 10(55), 58-67.

[10] Nalchadzhian, A.A. (2010). Psychological adaptation: Mechanisms and strategies. Moscow: Eksmo.

[11] Fress, P., \& Piazhi, J. (Eds.). (1975). Experimental psychology. Moscow: "Progress".

[12] Danylenko, N.V. (2019). Theory of instincts V.I. Horbuzov as a person's life. In Kharkiv autumn marathon psychotechnology: Materials of the III Interregional scientific and practical conference (pp. 99-102). Kharkiv: Disa plus.

[13] Maklakov, A.G. (2017). General psychology. St. Petersburg: Peter.

[14] Larsen, E.B. (2016). On preved. Needlessly without tolerate to himself. Moscow: Mann, Ivanov and Ferber.

[15] Sidorenko, E.V. (2007). Methods of mathematical care in psychology. St. Petersburg: OOO "Rech".

[16] Krutii, K.L., \& Zdanevych, L.V. (2017). Review of empirical research on the stratification of modern preschool childhood. In Development and modernization of social sciences: Experience of Poland and prospects of Ukraine (Vol. 2). (pp. 56-71). Lublin: Baltija Publishing.

[17] Sannikov, O. (2016). Information system operator: The structure and components of personal choice. Science and Education, 7, 133-143.

[18] Pyroh, H.V. (2020). Psychological features and problems of professional development of psychologists. In Personal growth in the conditions of transformation of modern society (pp. 192-200). Zhytomyr: Vydavnytstvo O.O. Yevenka.

\title{
Олена Анатоліївна Мірошниченко
}

Житомирський державний університет імені Івана Франка

10008, вул. Велика Бердичівська, 40, м. Житомир, Україна

\section{Психологічні передумови вікових відмінностей адаптації українських зимівників до умов життедіяльності в Антарктиці}

\begin{abstract}
Анотація. Актуальність статті грунтується на тому, що кожного року протягом 26 років на українську антарктичну станцію «Академік Вернадський» з метою проведення наукових досліджень відправляється експедиція зимівників, ефективна адаптація яких до екстремальних умов життєдіяльності передбачає якісну психологічну діагностику та рекомендації психолога. Метою цієї статті $є$ теоретичне обгрунтування та емпіричне доведення вікових особливостей адаптації українських зимівників до умов Антарктики. Для досягнення результатів дослідження у статті використано метод соціометричних вимірів Дж. Морено, метод розподілу ознак за рангом, анкетування. Проведено аналіз наукових робіт з проблеми дослідження, уточнено поняття «адаптація» та «адаптивність», обгрунтовано вікові межі груп досліджуваних зимівників, описано методологічний інструментарій та проведено емпіричне дослідження особливостей адаптації вікових груп зимівників. Обгрунтовано розподіл та виділено групи високої, середньої та низької адаптивності до життєдіяльності в екстремальних умовах Антарктики. Проаналізовано дані, отримані в результаті проведеного емпіричного дослідження, а також дані, отримані в процесі проведення бесід з досліджуваними зимівниками. Зроблено такі висновки: зимівники більш старшого віку мають більше досвіду адаптації до екстремальних умов, краще, ніж представники молодого покоління, вміють будувати міжособистісні стосунки в замкнутому колективі, краще переносять віддаленість від домівки й тугу за близькими. 3'ясовано, що особи більш старшого віку (особливо представники «Покоління дітей переможців») мотивами зимувати в Антарктиці називають бажання самореалізації, бути гідними представниками України на далекому континенті, відчути відповідальність за виконання своїх обов’язків. Зрештою, ними керують більше професійні та соціальні мотиви, які допомагають краще адаптуватися до екстремальних умов. Практична цінність роботи полягає у розробці інструментарію для проведення психологічної діагностики та наданні рекомендацій щодо відбору зимівників серед кандидатів на зимівлю
\end{abstract}

Ключові слова: особистість, адаптивність, вікові групи, покоління сучасності, екстремальні умови життєдіяльності 